\title{
A Meditação Bíblica de Gonçalves Dias
}

Cilaine Alves Cunha ${ }^{1}$

Resumo: A prosa poética de Gonçalves Dias, Meditação, dramatiza as violentas contradições que atravessaram o decurso histórico da América portuguesa e do Brasil independente, em especial o extermínio dos índios e a escravidão. Incorpora tópicos do historicismo de Herder e de Friedrich von Martius para representar esses dois períodos como uma lenta experiência de decadência nacional. Nessa hermenêutica cristã, o declínio do Brasil livre está previsto em seu passado colonial. Este texto discute o historicismo de Gonçalves Dias, o abrandamento do mito fáustico como indagador insociável, o inacabamento formal e a discreta fusão de gêneros e estilos dessa obra.

Palavras-chave: Gonçalves Dias; Meditação; historicismo cristão.

Abstract: The prose poetry of Gonçalves Dias, Meditação, dramatizes the violent contradictions through the historical course of Portuguese America and independent Brazil, specially the genocide of indigenous peoples and slavery. Incorporates topics of the historicism from Herder and Friedrich von Martius in order to represent these two periods as a slow national decay experience. By this christian hermeneutics, independent Brazil's decay is foreseen on it's colonial past. This text discusses the historicism from Gonçalves Dias, the relaxation of the Faustian Myth as unsociable inquirer, the formal incompleteness and the discreet fusion of genres and styles of that work.

Keywords: Gonçalves Dias; Meditação; christian historicism

1 É Professora de literatura brasileira no Departamento de Literatura Brasileira da Universidade de São Paulo. 


\section{História Profética do Brasil ${ }^{2}$}

Gonçalves Dias compôs a prosa poética Meditação entre 1845 e 1846, quando retorna ao Brasil após dar por encerrado seus estudos jurídicos em Portugal, antes, porém, de se instalar definitivamente no Rio de Janeiro e de se consagrar poeta da nação. Algumas passagens do texto evidenciam o olhar de quem, mal acaba de chegar, indigna-se com as iniquidades do país escravocrata e seus efeitos sobre a vida cultural da nação. Um dos narradores estranha o atraso econômico impresso na falta de planejamento das cidades, em suas ruas tortuosas e na feição rústica de seus edifícios e monumentos.

O enredo de Meditação gira em torno de um conflito entre a antiga e a nova tradição, entre o Brasil colonial e o país independente, representados por seus dois protagonistas, respectivamente o cético Velho e o Jovem letrado idealista, assim nomeados no texto. Analogamente ao artigo de Gonçalves de Magalhães, "Discurso sobre a história da literatura brasileira", responsável por estabelecer uma periodização da história da literatura no Brasil, o de Gonçalves Dias funciona, a seu modo próprio, como uma declaração de princípios para nacionalizar a literatura. A este projeto mais ambicioso e bem menos otimista que o de seu contemporâneo, Dias acrescenta propostas para tirar o país de seu crônico atraso econômico e social, fundamentadas numa ácida e lúcida análise das contradições da sociedade brasileira. Partilhando do gênero dramático, o diálogo entre os dois protagonistas procura também avaliar e ponderar a possibilidade de adaptar os fundamentos do nacionalismo aos traços peculiares da sociedade local, em especial a escravidão.

Ao longo do texto, a viagem de Dante pelos círculos do inferno funciona como inspiração ao deslocamento imaginário do Jovem pelas imagens de degradação social do Brasil ao longo de sua história. Analogamente à reação de Dante diante do inferno, a personagem juvenil de Meditação desmaia a cada uma dessas imagens que o Velho the apresenta. Mas para tecer o enredo e plasmar a estrutura de sua narrativa, Gonçalves Dias, seguindo o exemplo de Alexandre Herculano em $A$ voz do profeta (1836), ${ }^{3}$ apropria-se de Palavras de um crente (1834), de Lamennais. Como este, empresta o

2 Uma versão parcial deste texto foi produzida como capítulo de minha tese de doutorado (2000) e como exposição oral durante o XI Encontro Regional da Abralic (Associação Brasileira de Literatura Comparada), em 2007.

3 Para uma discussão sobre o diálogo de Meditação com $A$ voz do profeta, cf. MARQUES, Wilton José. Gonçalves Dias, o poeta na contramão. Literatura e escravidão no romantismo brasileiro, op. cit. 
estilo grave e o ritmo de versículos do Apocalipse, organizando curtos parágrafos recorrentemente interligados pela repetição enfática da conjunção "e". Meditação valese ainda de outro recurso do autor francês quando lança mão de parábolas para traçar sua leitura da história do Brasil e concretizar sua análise sobre a vida social brasileira.

O narrador de Lamennais procura, num tom apocalíptico, proteger o dogma católico contra a tentativa da monarquia de instrumentalizá-lo em favor dos princípios legitimistas. Remonta as tendências democráticas e socialistas ao Evangelho para, ao fim, conceber uma espécie de socialismo cristão. O narrador se representa ao modo do autor, como um padre que, dirigindo-se a um interlocutor, o Filho do homem, indagalhe o que ele vê. Suas visões conformam a história da humanidade em duas etapas, uma relativa ao Antigo Regime, e outra ao período pós-revolucionário, quando haveria de ter iniciado a autonomia das nações e a distribuição equitativa de seus bens, respeitando a soberania popular. Após cada uma das visões do Filho do homem, o narrador, como em sermões, retoma a palavra para condenar toda forma de dominação, apelando aos fiéis que se revoltem contra a escravidão e o trabalho dito formal, entendidos como crime contra a humanidade. Lamennais avalia este último modo de produção como uma nova forma de tirania, fruto de forças demoníacas que tomariam de assalto o homem vicioso. Por essa prática, o proprietário, diz o narrador, estimula a concorrência entre os trabalhadores para formar o que hoje se entende por grande exército de reserva e, nessas condições, produzir mais-valia. ${ }^{4}$ Em sua ótica, a pobreza, a fome e a miséria resultam da concentração de renda e da propriedade privada, o que nega aos pobres o direito sagrado à terra e ao trabalho: "Cada um tem direito de conservar o que tem, desde que os outros não fiquem sem nada". ${ }^{5}$ Diante disso, o narrador exalta a fraternidade entres os povos e conclama os pobres das nações a se unirem em rebeldia contra a opressão. ${ }^{6}$ Nesse cenário, o recurso a parábolas torna-se circunstancial, servindo de pretexto à pregação religiosa e ao proselitismo político. As profecias de Palavras de um crente que conformam as etapas da história da humanidade são rápidas, o que leva o discurso do orador sobre seu presente a se sobrepor-lhes em extensão.

Meditação, por sua vez, divide-se em três capítulos, cada um com sete, treze e treze subcapítulos, respectivamente. No primeiro capítulo, o tempo da ação é contemporâneo ao da enunciação, prestando-se a uma análise das condições sociais do Brasil independente. O segundo capítulo avalia o papel dos intelectuais diante desse

4 Cf. LAMENNAIS. Les Paroles d'un Croyant, op. cit., p. 29.

5 Id., ibid, p. 31.

6 Id., ibid, p. 23. 
quadro, observando os obstáculos à adoção dos princípios nacionalistas, oferecidos pelo sistema escravacrota e pela prática dos letrados em geral. O último traça duas etapas para a história do Brasil, uma antes e outra depois da invasão portuguesa, para retomar e se encerrar com a análise sobre a nação livre. Gonçalves Dias substitui a história da humanidade, em Lamennais, pela particularidade brasileira, associando o antigo regime aos séculos da colonização portuguesa. Essa historicização apocalíptica busca no passado o germe dos males que assolam o país. Nesse sentido, as parábolas são recurso fundamental para mapear, nas contingências sociopolíticas do século XIX, os resíduos do passado.

Para desenvolver o conflito entre o velho e o novo, o autor atualiza a tópica do contraste entre a velhice e a juventude como fator de equilíbrio e conquista do ideal nacionalista. A sabedoria e a prudência, tradicionalmente atribuídas à primeira delas, coadunam-se com o lugar comum sobre a segunda, dizendo que seja a fase da vida em que predominam a imaginação, a reflexão e, assim, a capacidade para renovar.

Ao longo do primeiro e em parte do segundo capítulo, o ácido diálogo entre a consciência anciã e a juvenil privilegia a análise dos fatores que impedem o desenvolvimento do país. Em momentos tensos da discussão, o Velho vidente suspende o debate para apresentar ao Jovem cenas e situações que evidenciam as dificuldades para implementar o progresso nacional, sintetizadas na colonização, na escravidão, na importação de ideias e na prática política disseminada pelo país, tida por viciosa. As parábolas deixam de ser, com isso, mero pretexto para o discurso proselitista, tornandose instrumento de representação da sociedade brasileira.

Nesses momentos de acirramento das divergências entre os protagonistas, por três vezes o Velho toca as pálpebras do Jovem. Como em gêneros de viagem de ascensão ao céu a consciência juvenil apreende toda a geografia e a história do país, mas, sobretudo, sua estrutura sociopolítica. O toque mágico pelas pálpebras do protagonista patriota funciona como fator de indeterminação do espaço e do tempo em que o diálogo se desenrola. Como estes não se particularizam, as sucessivas imagens alegorizam o Brasil em geral. As personagens tornam-se espectadoras imediatas dos quadros que compõem a história do Brasil desde tempos imemoriais da cultura indígena, passando pelo período colonial até as lutas do período regencial. A viagem da alma do Jovem letrado nacionalista por essa imensidão espaço-temporal permite-lhe reconstituir uma singular compreensão da experiência social no Brasil que põe em xeque suas utopias. 
$\mathrm{Na}$ primeira viagem, o Jovem contempla imagens exuberantes da natureza tropical e sucessivamente correntes que atam os escravos uns aos outros, formando longos círculos que envolvem e sustentam a camada de homens brancos, livres e proprietários:

E esses homens formam círculos concêntricos, como os que a pedra produz caindo no meio das aguas plácidas de um lago.

E os que formam os círculos externos têm maneiras submissas e respeitosas, são de cor preta; - e os outros, que são como um punhado de homens, formando o centro de todos os círculos, têm maneiras senhoris e arrogantes, - são de cor branca.

E os homens de cor preta têm as mãos presas em longas correntes de ferro, cujos anéis vão de uns a outros - eternos como a maldição que passa de pais a filhos. ${ }^{7}$

A justaposição da imagem vigorosa da paisagem nacional à do inferno social brasileiro presta-se a negar a ideologia de que a magnitude da natureza tropical por si só garantiria o ingresso futuro do país na era da civilização, ideologia que já circulava entre patriotas poetas românticos. $\mathrm{Na}$ cena infernal da escravidão, a gratuidade da violência com que os senhores tratam os escravos, o tapa inesperado que um infame sinhô-moço desfere em um velho escravo, o empurrão que este recebe de outro jovem branco por ter reclamado do primeiro, todas essas imagens formam um quadro fotográfico estático da irracional exploração do trabalho. Como as cenas não se desenvolvem narrativamente, sendo energicamente postas diante dos olhos do leitor, essas imagens visuais demonstram a intenção do autor de documentar a escravidão de modo plástico e patético, o que desvela seu realismo criticamente romântico.

Em seguida o Velho desloca o olhar do Jovem para edificações, ruas, vilas e cidades do Império. Na imagem que as representa, os habitantes correm apressadamente e a esmo, evidenciando carência de juízo na determinação das prioridades da vida, como se se entregassem ao livre curso do acaso ou, num termo do narrador, como se estivessem à mercê do destino. Confirmando essa suposta carência de prioridades, as ruas estreitas, tortuosas e mal calçadas, a falta de elegância e a ausência de um projeto arquitetônico para templos e palácios, a precariedade dos meios de transportes, reduzidos a jangadas e canoas de um só toro de madeira, toda essa insuficiência revelaria aos espectadores a falta de controle do ritmo da vida pela necessidade. Ante essa situação, o Jovem reage ironicamente numa sequência de frases curtas, anafóricas e enfáticas que imitam a sua indignação:

7 DIAS, Gonçalves de. Meditação, in: Poesia completa e prosa recolhida, op. cit. p. 742. 
E nessas cidades, vilas e aldeias, nos seus cais, praças e chafarizes - vi somente - escravos!

E no adro ou debaixo das naves dos templos - de costas para as imagens sagradas, sem temor, como sem respeito - escravos!

E nas jangadas mal tecidas - e nas canoas de um só toro de madeira - escravos; por toda a parte - escravos!!...

Por isto o estrangeiro que chega a algum porto do vasto império consulta de novo a sua derrota e observa atentamente os astros porque julga um vento inimigo o levou às costas da África.

E conhece por fim que está no Brasil - na terra da liberdade, na terra ataviada de primores e esclarecida por um céu estrelado e magnífico! ${ }^{8}$

Nessa análise cultural do país, não constrói tradição, nem favorece o cultivo do sentimento nacional o país cuja população está privada de liberdade. Para o Velho, a escravidão impede a gestação e a livre expressão do pensamento do "povo" brasileiro, bem como a sedimentação de sua Ideia característica em monumentos e edificações, emperrando, assim, a formação da tradição local. As nações, segundo ele, progridem numa dinâmica histórica marcada pela ascensão, apogeu político e cultural, seguidos da queda. Antes de seu período áureo, predomina a idade da força guerreira, quando heróis locais lutam contra o jugo de outra nação, sobrepujando-a e mesmo conquistando outros povos. $\mathrm{Na}$ idade da razão, por sua vez, o Espírito nacional se imprimiria em seus costumes e edificações arquitetônicas, na história e na cultura em geral. Para que supere a fase jovem, ingresse na maturidade e conquiste a civilização seria necessário constituir uma tradição local pela retomada, nessa ótica, da autoridade e exemplo de seu passado, o que a suposta prática de importação das ideias no Brasil emperrava. Na sociedade escravagista, ruas, casas, palácios e templos careciam de graça, já que o belo nacional, nessas condições, não grava o Espírito das épocas e deixa de sedimentar, multiplicar e perpetuar ideias morais, religiosas e culturais.

Meditação entende a escravidão como um sacrifício que vitimou não o indivíduo, mas antes o povo brasileiro, dizimando, nessa ótica, os princípios do útil, do belo e do justo: “'Os gregos realizaram o belo-ideal; e os árabes, tentando realizá-lo, transformaram a sua tenda de um dia em habitações duradouras; porque eles eram livres nos atos e nos pensamentos - livres, como o simum dos seus areais". ${ }^{9}$ Ignorando a presença da escravidão entre gregos e árabes, o Velho postula que eles teriam passado "do reinado das armas ao reinado da inteligência, para adormecerem sobre o fruto dos seus trabalhos, como o vindimador junto aos cestos que ele mesmo enchera de 
apetitosos cachos". ${ }^{10}$ Nessa suposta lição do passado, a cristalização do belo em monumentos nacionais realiza-se quando os indivíduos se dispõem voluntariamente ao trabalho. Mas, no Brasil, o sistema escravocrata desencadeava, para o ancião, a recusa pelo homem livre a assumir o trabalho de construção da infraestrutura do país. Ao negar que o trabalhador colhesse o "fruto do suor de seu rosto", a escravidão tornava o trabalho abjeto e disseminava a inércia e a ociosidade pela população:

E o escravo não pode ser arquiteto, porque a escravidão é mesquinha, e porque a arquitetura, filha do pensamento, é livre como $o$ vento que varre a terra.

E o escravo será negligente e inerte, porque não lhe aproveitará o suor do seu rosto; porque a sua obra não será a recompensa do seu trabalho; porque a sua inteligência é limitada, e porque não tem o amor da glória.

E o homem livre dará de mão às boas-artes, porque não quer ombrear com o escravo, que é infame e desonroso.

E não se dará às artes mecânicas, que são o emprego do liberto e daqueles que não são homens.

E não se dará à marinha, esse potente veículo do comércio e da civilização, porque a marinha está inçada de escravos.

E se os seus vestidos roçarem a opa do escravo, ou a esclavina do liberto, ele os sacudirá com asco; e se a sua mão tocar amigavelmente a mão do escravo, ele a cerceará do pulso - como pois o chamará colega? ${ }^{11}$

Um dos principais alvos de Meditação encontra-se, assim, na extinção da escravidão e na defesa da ética burguesa do trabalho. Ainda que indignado com a disseminação da violência pelos estratos sociais, a prosa poética de Gonçalves Dias desloca a discussão sobre seus efeitos na vida do indivíduo. O cruel racismo da primeira metade do século XIX leva o Jovem a supor que "as artes mecânicas", como se nomeavam trabalhos manuais, sejam "o emprego do liberto e daqueles que não são homens". A atenção do diálogo montado entre Jovem e Velho prende-se antes à suposta improdutividade do indivíduo pobre e livre.

Para traçar o balanço sobre o grau de civilização no Brasil, Gonçalves Dias adapta, a seu modo iluminista próprio, os pressupostos filosóficos de Herder. Como neste, Meditação entende que a história da humanidade, desde os povos egípcios, gregos e romanos, atravessou respectivamente a infância, a adolescência e a maturidade. Reivindica enfaticamente a especificidade local, supondo que as noções se desenvolvem num processo análogo ao da vida biológica, germinando, crescendo e morrendo numa lenta decadência. Como em Herder, Meditação adota o critério metodológico que recorta e separa os campos da cultura como objeto da investigação da história geral de 10 Id., ibid, p. 746. 11 Id, ibid. 
um povo, tomando seus monumentos arquitetônicos e artísticos como fenômenos que guardam resíduos do passado.

Gonçalves Dias distancia-se, no entanto, do filósofo alemão por adotar a crença de que a evolução da história da humanidade implica necessariamente um processo de aperfeiçoamento progressivo da razão. Mas o anti-iluminismo herderiano nega o pressuposto e duvida que essa evolução vise algum fim ou mesmo que o fluxo da história obedeça a uma razão única - ou alheia às leis de uma comunidade - e que determine com exclusividade o sentido de sua existência, seu modo de organização interna e a regulação entre seus membros. Marcada por fenômenos múltiplos, cada nação possui, em Herder, seu próprio "centro de felicidade" que pode, inclusive, modificar-se de uma época a outra. Para ele, a cultura que transforma o esclarecimento em fim encontra-se numa etapa de decadência, ao contrário de Gonçalves Dias que o toma como necessidade universal. O trabalho de formação é, em Herder, processo, não resultado, configura-se na duração. ${ }^{12}$ A força libertária de seu pensamento abala a própria crença na perfeição humana. Numa analogia com sua compreensão acerca do desenvolvimento da história, mesmo a natureza humana, para ele, resulta de um enorme processo de diferenciação e individualização, em constante modificação. ${ }^{13}$

Sua reação ao racionalismo e à hegemonia cultural francesa sobre seu país encontra-se entre os diferentes fatores que o impelem a supor que, ao lado de forças divinas, o acaso e o destino também possuem papel dinâmico na ação transformadora do tempo, o que acentua a ambiguidade de sua filosofia da história. Nem progressão orientada para maior felicidade e virtude, nem alternância entre esta e o vício, a totalidade de fatores que impelem o movimento da história é, para Herder, inapreensível. Resultado de múltiplas forças em contato, a suposta progressão da humanidade obedece, diz ele, a momentos de repouso, revolução e transformação. Sem incorrer em niilismo, antes em uma solene simpatia com diferentes culturas, seu relativismo reconhece a insuficiência da linguagem para interpretar o caos da história em seus múltiplos fatores determinantes:

Conseguisse eu ligar entre si as mais díspares cenas, sem as confundir, mostrar como se relacionam umas com as outras, como crescem umas a partir de outras, como se perdem umas dentro de outras, mostrar que cada uma por si é apenas um momento, mas que todos os momentos tomados na sua progressão são meios orientado para fins.... Que perspectiva não obteria! Que aplicação mais nobre se poderia esperar

12 Cf. JUSTO, José M. "Posfácio" a HERDER. Também uma filosofia da história da humanidade, op. cit., p. 157-158.

13 Cf. MEINECKE. El historicismo y su genesis, op. cit., p. 323-324. 
para a história humana? Que encorajamento não se encontraria aí para a ação, para a esperança, para a fé? Mesmo quando não se vê, ou quando não se consegue ver tudo! Adiante... ${ }^{14}$.

Por pressupor, conforme se verá, uma ação exclusivamente divina na orientação dos eventos da história do Brasil, por concebê-la como força nacional racionalista e, sobretudo, por adotar a máxima de que a história seja mestra da vida, o historicismo que atravessa Meditação aproxima-se do pensamento histórico de Friedrich von Martius. Gonçalves Dias adere à compreensão de Martius de que a ação das três "raças" fornece o sentido da história brasileira, além de considerar dominante, como este, a força da natureza tropical sobre o ethos local.

Em seu texto premiado pelo Instituto Histórico e Geográfico Brasileiro, ${ }^{15}$ Martius propõe que a escrita da história do Brasil deve mostrar como e em que medida particularidades físicas e morais de cada um dos três povos ofereceram-se como seu motor essencial. Se a providência predestinou o Brasil, diz o autor, à mescla racial, no futuro "o sangue português, em um poderoso rio deverá absorver os pequenos confluentes das raças Índia e Ethiópica". ${ }^{16}$ Martius prende, em boa medida, a escrita da história do Brasil ao interesse da monarquia de reescrever o passado em favor da naturalização de sua hegemonia.

Aconselha que essa narrativa relate como heroica a ação das milícias colonizadoras pelo interior do Brasil. Procurando conter o antilusitanismo disseminado nos círculos letrados, enfatiza que a ação marítima, comercial e militar da colonização portuguesa seja pintada como façanha e com energia plástica. Exalta as construções jesuíticas como único monumento grandioso em meio às demais ações de outras ordens religiosas. $\mathrm{Na}$ concretização da escrita da história brasileira, Martius propõe que os colonos do século XVI sejam diferenciados daqueles do século XIX. Constituídas por príncipes e nobres, as imigrações iniciais teriam resultado de seus esforços para enriquecer e fortalecer a nação portuguesa em geral. Os colonos oitocentistas, por sua vez, predominantemente agricultores e artistas, visavam, sob essa ótica, à mera fortuna individual e ao arrivismo. Perpetuando o princípio de que o passado é exemplo do futuro, Martius define como tarefa da história do Brasil "despertar e reanimar em seus leitores amor da pátria, coragem, constância, indústria, fidelidade, prudência, em uma

14 HERDER. Também uma filosofia da história da humanidade, op. cit., p. 46.

15 Embora o resultado do concurso organizado pelo Instituto Histórico e Geográfico Brasileiro tenha sido proferido em 1845, o texto de Martius, "Como se deve escrever a história do Brasil", foi publicado antecipadamente em 1844, na revista deste Instituto.

16 MARTIUS. "Como se deve escrever a história do Brasil". Revista do Instituto Histórico e Geográfico Brasileiro, op. cit., p. 383. 
palavra, todas as virtudes físicas". ${ }^{17} \mathrm{O}$ livro dessa história deveria ser planejado para os muitos habitantes da população brasileira afeitos a "ideias políticas imaturas", procurando convencer "os republicanos de todas as cores" da inconveniência de suas utopias aos negócios ali nomeados de "públicos". ${ }^{18}$

Martius destina rápidas palavras à contribuição da cultura africana para o desenvolvimento da história portuguesa e brasileira. Limita-se a destacar que ela remonta a um período anterior à invasão do Brasil, durante as explorações comerciais na África. Aborda, no entanto, com mais vagar a cultura indígena.

Para ele, caberia ao historiador deslocar a "raça americana para uma época encoberta de escuridão", aceitando que ela estivesse envolta por enigma. Na tarefa de esclarecê-la, o estudioso deveria explorar sua língua, o tipo de relação "social" e "jurídica" estabelecida entre seus membros e com outros povos, seus monumentos, mitos, geogonia, teogonia, ruínas, sítios arqueológicos etc. Para me valer de Salgado Guimarães, Martius adota critérios iluministas para a sondagem da cultura indígena, selecionando por fatores determinantes de uma sociabilidade apta a se transformar em objeto da história os que eram recorrentes entre as populações europeias, tais como:

[...] unidade linguística, àquela altura um dos critérios centrais para a possibilidade de fundamentar uma identidade nacional $\mathrm{e}$ as reivindicações políticas daí decorrentes; presença de trocas regulares entre os grupos humanos; uma concepção de poder político que o faz derivar de uma noção de contrato e não de submissão; o trabalho coletivo como regularidade da vida social". ${ }^{19}$

Ainda conforme Salgado Guimarães, uma vez que esses critérios não são apropriados para representar o indígena, o historiador alemão envolve-o em mistério. Desconhecendo a exigência de que o caos da história se organize por relações de causa e efeito, em sequência, simultaneidade e sentido marcado pela evolução rumo à civilização, aos indígenas do Brasil faltariam, enfim, as condições próprias de acesso à história. Nessa ótica, eles deixam de contribuir para a formação histórica do Brasil desde que também careciam de

[...] contatos regulares entre os diferentes grupos que permitissem a constituição de um sentido de pertencimento e coletividade; à língua destes grupos faltariam expressões que denotassem "um refinamento dos sentidos", assim como expressões explicativas da origem do universo que os rodeava. Faltavam-lhes ainda meios de expressão capazes de articular o passado a um presente, levando von Martius a afirmar que faltava-lhes, no conjunto, articulação (Zusammenhang),

17 Id., ibid., p. 400.

18 Id., ibid., p. 401.

19 GUIMARÃES, Manoel Salgado. "História e natureza em von Martius: esquadrinhando o Brasil para construir uma nação", in: História, Ciências, Saúde - Manguinhos, op. cit. 
entendida como a capacidade de organizar o pensamento segundo princípios de causa e efeito. Incapacidade, em suma, de definir uma origem segundo as exigências de uma história herdeira das tradições das Luzes e fixada como disciplina no século XIX. Ao faltar-lhes história, faltava-lhes, segundo von Martius, a medida do exemplo - a história como mestra na formulação clássica ciceroniana! - e portanto a força para as realizações mais nobres do espírito. [...] Sem passado e sem futuro pareciam condenados a um eterno presente, incapazes assim de preencher as exigências de uma historicidade pensada como articulação de uma tripla temporalidade: passado, presente e futuro. ${ }^{20}$

Ao recompor o modo de ser dos autóctones pela falta essencial, Martius deduz que eles se encontravam em avançado estágio de queda, mas apresentando vestígios de uma civilização muito antiga e perdida.

Em um dos aspectos de seu historicismo de que Gonçalves Dias mais se aproxima, o historiador alemão, já desde seus relatos de viagem de 1823, interpreta negativamente a ação da natureza tropical sobre os habitantes locais, tidos por rudes e primitivos. A natureza determina, nessa ótica, a experiência social brasileira. Dominado por sua exuberância, a população viveria aqui sobre a ação da razão instintiva e sensível, natural e espontânea, mais propícia à contemplação que à ação. A vivência sob o efeito de natureza implica, em Martius, o desinteresse da população local por questões do espírito, por frequentar bibliotecas e salas destinadas a eventos literários, por se informar sobre o mundo político em leituras de jornais, nem por constituir laços estreitos de sociabilidade. Preso à riqueza natural, o "povo" brasileiro preferia, nessa ótica, a vida isolada. Por tudo isso, alienava-se do mundo cosmopolita. Em outro aspecto que leva Gonçalves Dias a supor que o Espírito nacional não se constituía, nem se imprimia em monumentos e edificações arquitetônicas brasileiras, Martius postula, em 1823, que o distanciamento do mundo da cultura poderia ser observado na dificuldade de o brasileiro desenvolver o senso artístico na pintura e na escultura, o que o levaria a compor não obras de artes, mas meros ornamentos, ainda que ricos. ${ }^{21}$

Como ele, Gonçalves Dias traça a história do Brasil considerando a presença aí dos três povos e culturas, mas distribui diferentemente a participação de cada um deles. É fato que inverte satiricamente o heroísmo com que Martius pinta a ação portuguesa ao longo dessa história. Observa-se ainda que, enquanto o naturalista transforma a alienação em efeito da natureza, o poeta, conforme se verá, põe em debate a negação de alguns direitos individuais, especialmente a educação. 
Em que pesem as diferenças, o autor de "Canção do exílio" adota a hipótese de que o indígena do tempo não vivia em estado primitivo heroico, mas em alto grau de declínio. As discordâncias aí referem-se aos fatores que desencadearam o seu extermínio. Ao tomar a degradação da cultura indígena como resultado da força moral e intelectual do vencedor, Martius a naturaliza e livra, assim, a colonização de sua responsabilidade pelo genocídio dos aborígenes. Gonçalves Dias, por sua vez, rechaça a opressão imperialista. Mas como naquele, compreende que a história do autóctone contou com um período áureo situado em primórdios imemoriais. Nos dois casos, a interpretação de que eles sejam um povo decaído pode se conformar a um processo de extinção que não era tão absoluto como supunham.

Meditação silencia o legado do povo africano no Brasil, a não ser quando rapidamente computa entre os tipos locais os homens de "cor mestiça" ao lado de brancos e índios. No poema do autor, "A escrava", o agudo sentimento de saudades da África alimentado por Alsgá sobrepõe-se a sua reação diante da privação de sua liberdade e da violência sofrida com intensos trabalhos forçados. Para o sujeito lírico, seu crescente desatino interior só poderia ser estancado com seu retorno definitivo ao continente africano. Assim fazendo, reforça a negação do direito do afro-brasileiro à cidadania local.

A natureza ganha força negativa também em Meditação. Além da escravidão, Gonçalves Dias associa a ação do fenômeno natural ao atraso do país. Neste texto, o desejo de introduzir, no Brasil imperial, a ética burguesa do trabalho realiza-se por meio de metáforas extraídas do mundo natural. Nesse ascetismo dito esclarecido, trata-se de transpor, para o suposto modo de vida carente de objetivos, o significado das águas de um rio entregues às suas próprias forças. Sem qualquer trabalho de encanamento, o povo pobre, vivendo em estado de natureza, pode, como num dilúvio, transbordar, ensopar e destruir campos. Para o Velho de Meditação, a fé do Jovem no progresso nacional não se sustenta num país em que seus habitantes vivem como navio sem lastro. A tarefa de "formação" da população local implica, segundo ele, um processo análogo ao domínio do mundo natural. Para um plantio útil e uma boa colheita, devem-se adubar os campos, já que não se colhem frutos de solo indomado. Assim também o pobre dito livre deveria sofrer um processo de condicionamento moral e religioso para dar bons resultados no dito caminho da verdade, luz, trabalho e progresso. ${ }^{22}$ Nessa hipervalorização do código de ética nacional, o Brasil poderia, quem sabe, ingressar 22 DIAS, Gonçalves de. Meditação, in: Poesia completa e prosa recolhida, op. cit., p. 753. 
numa era "civilizada" se adotasse o interesse do Jovem letrado de instituir o trabalho formal e introduzir, na prática política, o útil e o justo.

\section{Os Períodos da História do Brasil}

Ao longo de Meditação, uma origem ideal e virtuosa contrapõe-se a diversas razões que representam a história do Brasil como falta. Concebida como uma utopia moral, esses primórdios desenham-se a partir da inversão de aspectos negativos do presente histórico. Para representar a cultura indígena primitiva, Gonçalves Dias substitui o pressuposto da repetição dos vícios ao longo do fluxo da história colonial pela hipótese da presença dominante e constante da virtude na cultura indígena originária. Nessa invenção heroica do passado como exemplo do futuro, mas abortado no presente, forja-se o conflito entre o ideal nacional e o real, tomando este como obstáculo daquele. A vida dos aborígenes situados num passado mítico constrói-se por meio de uma verossimilhança assentada não na etnografia e na pesquisa sobre essa cultura, mas considerando a ilusão nacionalista. Meditação recria e projeta na cultura antiga do aborígine ideais relacionados com a proposta de desenvolvimento do país.

Em seu terceiro capítulo, ante a insistência do Jovem quanto à viabilidade de seu projeto nacionalista, o Velho toca-lhe novamente os olhos, levando-o a visualizar a história pregressa do país e o que ele poderia ter sido. Contraposto ao modo de vida do escravo e do homem pobre e livre, o do índio torna-se um modelo ideal a ser recuperado no presente. Em seu figurativo modo de ação, eles morrem por amor à independência e lutam bravamente contra a dominação e a escravidão. Fazendo sua vida girar em torno do trabalho, tão logo nasce o sol dedicam-se imediatamente e prontamente ao arco e a flecha e cavam, assim, "a superfície das águas em direção contrária a sua corrente". ${ }^{23} \mathrm{~A}$ riqueza de sua cultura poderia ainda ser observada em seu obstinado senso religioso, praticado como culto à "figura do senhor no raio e no trovão". Nessa retrospecção das expectativas do presente, a comunidade indígena prestava respeito aos ancestrais e preservava o "espírito dos finados", vale dizer, heroicizavam seus antepassados e valorizavam suas tradições. Como no poema o "Canto do guerreiro", de Gonçalves Dias, a cultura indígena dota-se por fim de sensível juízo estético, cantando "os seus feitos aos sons retumbantes do boré" e adornando suas flechas com penas de mil cores.

No terceiro capítulo de Meditação, o segundo período da história do Brasil contempla desde a chegada dos portugueses até o momento imediatamente posterior à 23 Id., ibid., p. 759. 
emancipação, desaguando no presente da enunciação. Descrito como uma anomalia histórica que, no limite, teria originado todos os erros da política contemporânea, esse segundo período se opõe ao primeiro por fundar um tipo de regulação social baseada não em princípios éticos e religiosos, nem no amor ao trabalho, mas na exploração da mão-de-obra escrava e na ambição pelo ouro, o que teria feito disseminar a cobiça, a inveja, os crimes de vingança, a carência de sentimento religioso e toda sorte de vícios de indivíduo a indivíduo, família a família, geração à geração.

Em outro resultado da colonização, a vitória sobre os índios desencadeou necessariamente a futura derrota do vencedor. Gonçalves Dias antecede o início da decadência do Império português ao período colonial, supostamente originada pela ação contra a vida do autóctone. Ao exterminar os indígenas, Portugal, nessa ótica, se condenou ao fracasso. A conclusão desse longo processo de declínio situa-se na crise por que passa Portugal durante o século XIX, prefigurado, assim, no passado. Esse castigo divino é concebido, em Dias, como uma profecia que antecipa o futuro:

E viu Deus que a nação conquistadora se tinha pervertido, e marcou-lhe o último período de sua grandeza.

E deu-lhe uma longa série de anos para que ela lastimasse a sua decadência, e conhecesse a justiça inexorável do Todo-Poderoso.

Ela tornar-se-ia fraca, porque tinha escravizado o fraco - incrédula porque tinha abusado da religião - pobre porque sobremaneira tinha amado as riquezas - e curvada sob um jugo de ferro, porque tinha sido tirana.

E todas as nações do mundo passariam diante dela, comparando a sua grandeza d'outros tempos com a sua miséria de então.

E ela tornar-se-ia o opróbio das gentes, de maravilha que tinha sido. $^{24}$

Com esse defeito de germinação nasce o povo brasileiro que forja a Independência e sua organização social desrespeitando a diversidade de opiniões e mantendo a segregação social pela hierarquia das cores. Dando continuidade a esse sistema, Meditação encena um pacto, no momento posterior à Independência, entre brancos (os proprietários, o estamento político e os filósofos), indígenas e mestiços livres, contrato este que confirmou a preservação da escravidão e a permanência da antiga estrutura social. Perpetua-se, com isso, a suposta ociosidade do brasileiro e a hegemonia dos proprietários brancos que, tal como ocorreu após a invasão, se legitimam no poder pela posse do capital:

E os filósofos disseram:

"Os homens de cor preta devem servir, porque são os mais fracos, e é lei da natureza que o mais fraco sirva ao mais forte".

24 Id., ibid., p. 762. 
E os proprietários disseram:

"Os homens de cor preta devem servir, porque são o melhor das nossas fortunas, e nós não havemos de as desbaratar".

[...]

E os homens de cor branca também se levantaram e disseram:

"Nós constituímos a maioria da nação e somos dentre todos os mais ricos.

Fomos nós os autores da regeneração política e a inteligência é o nosso apanágio.

Ora, é lei da natureza que a alma governe o corpo; e que a sabedoria governe a ignorância.

Nós então ficaremos com o poder, porque somos os mais ricos e os mais inteligentes".

[...]

E os homens de raça indígena e os de cor mestiça disseram em voz alta: - "E nós, que faremos?

Qual será o nosso lugar entre os homens que são senhores, e os homens que são escravos?

Não queremos quinhoar o pão do escravo, e não nos podemos sentar á mesa dos ricos e dos poderosos.

E no entanto este solo abençoado produz frutos saborosos em todas as quadras de ano - suas florestas abundam de caça - e os seus rios são piscosos. livres.

Os brancos governam - os negros servem - bem é que nós sejamos

Vivamos pois na indolência e na ociosidade, pois que não necessitamos trabalhar para viver". ${ }^{25}$

Ao final de Meditação, um conselho formado por cinco homens procura decidir, após a Independência, qual melhor regime político a ser adotado. Mantendo a oposição entre experiência e idealismo, esse grupo também se compõe pelo confronto entre outro jovem letrado, um símile do primeiro, com quatro políticos idosos. Novamente o texto estabelece um confronto entre os ideais da mocidade com a antiga prática política que, ao governar tendo em vista a privatização do bem público, desencadeia o tráfico de influência e a discórdia como estratégia de controle do poder. $\mathrm{O}$ jovem defende $\mathrm{O}$ sistema de governo que pratique o bem, desperte no povo sentimentos de glória da nação e proporcione, com isso, a admiração dos políticos pela história afora. Da ótica dos velhos, no entanto, trata-se antes de garantir a sua hegemonia. Entre um tipo de política que procura apenas ser útil e outro que não cuida da glória, um deles replica que esta não passa de vaidade que se esquece de geração a geração. Diante do desconhecimento do povo acerca de sua força social, um dos velhos considera descabido o respeito a seus direitos. Tendo em vista ainda a brevidade da vida e o fato de que o "Rei dormia" (metáfora da Abdicação ou da Menoridade?), os velhos decidem espalhar a discórdia entre vencidos e vencedores e incitar a guerra. No auge da 
contenda, poderiam intervir como heróis protetores e conciliadores e recuperar sua autoridade.

Com esse diálogo final, Gonçalves Dias refere-se certamente aos anos iniciais do processo de emancipação do país que naquele momento caminhava rumo à consolidação do sistema político monárquico. Na ficcionalização desse período, opera uma caricatura das lutas do período regencial, quando a chamada reação monárquica aproveita a instabilidade política do país para submeter os revoltosos e restabelecer o controle político do país mediante a violência, a corrupção e o clientelismo. $\mathrm{Na}$ interpretação desses fatos, Gonçalves Dias entende que as revoluções regenciais teriam sido desencadeadas pelo próprio estamento político, na arcaica estratégia que divide para controlar. Disseminando a discórdia entre as várias facções, a elite monárquica pode se impor como agente conciliadora. Na cena final de Meditação, a punição que todos sofrem com um incêndio, metáfora de insurreição popular, demonstra o descaso com que as palavras do jovem foram recebidas. $\mathrm{O}$ fogo revolucionário carrega a moral implícita do jovem letrado "se tivessem me ouvido..."; e a do autor, "se não me ouvirem...".

O traço inacabado de Meditação não se deve apenas ao provável desaparecimento de algumas de suas partes. Deriva, sobretudo, do diagnóstico sobre a perpetuação dos costumes e códigos sociopolíticos da colônia no Brasil independente e à antevisão de um futuro problemático: o modo violento de produção e a prática política genericamente concebida como viciosa estendem-se ao longo de uma linha temporal sem fim. A repetição do antigo na nação livre leva o fluxo da história a se desenrolar como reprodução e confirmação permanente do mesmo ao longo das eras, e o texto a se fechar em círculo. Nessa adaptação da alegoria bíblica, os eventos do passado prefiguram os erros do presente.

Técnica de interpretação de significações sagradas, a hermenêutica cristã considera a presença de Deus nas coisas sensíveis, nos seres espirituais, puros espíritos, para ler a ordem e a estrutura do Universo como espelho da sabedoria divina. ${ }^{26} \mathrm{~A}$ alegoria bíblica pretende, diz Auerbach, mostrar que coisas, pessoas e acontecimentos do Velho Testamento prenunciam os do Novo e sua história de redenção. Concretos em referência a coisas ou pessoas, os acontecimentos e personagens do mundo empírico figuram leis divinas em coisas passadas e futuras. Os eventos da história são interpretados como veículo de um significado oculto em um tempo, mas revelado em 26 Cf. HANSEN, João Adolfo. Alegoria, op. cit., p. 92. 
outro. ${ }^{27}$ Se no Velho Testamento o significado é encoberto, no Novo ela se dá a ver plenamente. ${ }^{28} \mathrm{Na}$ intersecção entre um e outro evento dispostos longinquamente, o preenchimento da relação analógica entre os dois considera o acontecimento histórico provisório, mas contendo a promessa dos fins do tempo. $\mathrm{O}$ primeiro deles significa não apenas a si mesmo, mas também o segundo, enquanto este abrange e preenche o primeiro. Os dois polos da figura estão separados no tempo, mas, como acontecimentos ou figuras humanas históricas que são, inserem-se na corrente da história. Narrando fatos passados que predizem o futuro, seu significado completo se manifesta nos fins do tempo, mas já se anunciara antes. Na profecia figural, o primeiro acontecimento aponta para a encarnação e a proclamação do Evangelho, e o segundo não se realiza como preenchimento último, trazendo em si, diz Auerbach, uma "promessa dos fins dos tempos e do verdadeiro reino de Deus". A história universal torna-se, assim, eterna e inexorável, preenchida que é pela providência que lá sempre esteve, está e estará. ${ }^{29}$

Para dizer da essencialidade inexorável e da impossibilidade de inserção do país no progresso, Gonçalves Dias modela a história da América portuguesa e do Brasil independente de acordo com a progressividade temporal da profecia bíblica. A teleologia cristã determina que essa história se realiza de acordo com a sucessividade da gênese paradisíaca, o pecado original e o juízo final. $\mathrm{Na}$ linearidade infernal de Meditação, o desvio, pelos portugueses, da história do Brasil de uma origem supostamente virtuosa, prescrita por desígnios divinos, impôs ao país uma finalidade maldita. Em meio a esse desvirtuamento, emergem aqui e ali marcas da presença divina que procura interferir nesse curso maligno por meio de sinais que prescrevem seus mandamentos e impõem a sua ira: "E viu Deus que a nação conquistadora se tinha pervertido, e marcou-lhe o último período de sua grandeza./ E deu-lhe uma longa série de anos para que ela lastimasse a sua decadência, e conhecesse a justiça inexorável do Todo-Poderoso". ${ }^{30}$ No estado ideal de origem abortado, a história poderia ter caminhado desde uma condição predominantemente idílica, em meio a uma improvável harmonia entre os seres humanos, e destes com sua comunidade e com a natureza. Mas as ações imperialistas substituíram esse curso temporal por uma permanente decadência. Ao disseminar a corrupção por espaços e tempos afora, o imperialismo português não teria

27 Cf. AUERBACH. Figura, op cit., p. 31.

28 Id., ibid., p. 35-36

29 Id., ibid., p. 50-51.

30 DIAS, Gonçalves de. Meditação, in: Poesia completa e prosa recolhida, op. cit., p. 762. 
se dado conta da ação divina que então lhe prescrevera uma lenta e progressiva expiação.

Como na hermenêutica cristã, Gonçalves Dias estabelece semelhanças entre eventos passados e atuais. Reproduzindo a máxima de que o acontecimento pretérito seja exemplo e contraexemplo do presente brasileiro, entende que a história do Brasil estava previamente traçada desde sempre, de tal forma a repetir perpetuamente o mal. Em Meditação, "o novo está latente no passado e o antigo se patenteia no novo". ${ }^{11}$ As profecias do Velho tornam-se fundamentais para que se possa reconhecer nos tempos remotos do Brasil os sinais de seu defeito de origem e o vaticínio de um futuro que confirma e repete eternamente o que já estava escrito como uma essência ou perdida, ou corrupta. Analogamente ao sacrifício de Isaac, interpretado no Novo Testamento como prefiguração do martírio de Cristo, Gonçalves Dias toma o extermínio dos índios e a escravidão como figuras da perpétua imolação da nação e do povo brasileiro.

O extermínio indígena, a improvável carência do sentimento religioso no povo lusitano, a cobiça como suposto traço predominante de seu caráter, tudo isso prenuncia, em Meditação, que o Brasil seja desde sempre decadente. Seu futuro pode ser antevisto no exemplo do Império português. O primeiro evento dessa história viciosa, o extermínio do povo indígena prediz a futura adoção da escravidão e, no país independente, a sua preservação. Numa reação em cadeia da ira divina, se a dominação sobre índios e africanos determinou o início da decadência do império português, as ações políticas do período posterior à Independência do Brasil repercutem o mesmo erro. Se o pacto realizado após a emancipação política já se encontra inscrito na política colonial, assim também o futuro do Brasil pode ser antevisto na bancarrota do império português em curso. Na última cena de Meditação - em que os velhos políticos pagam o preço da cobiça ardendo no fogo que eles mesmos fizeram alastrar - o poeta interpreta a perda de controle da ação política incendiária como punição divina contrária à preservação da escravidão. Inadvertidamente, o pacto selou o destino do Brasil como um país cuja história se desenrolaria permanentemente por meio de uma eterna guerra civil:

E o povo e o Rei dormiam tranquilos; e os atalaias fascinados com a luz das suas fogueiras não viram esse meteoro aziaga que alumiava as trevas no meio da noite.

Porém viram-no os homens dos campos, e correram tumultuosamente, acudindo ao convite do sangue, que os Grandes lhes faziam.

31 BOSI, Alfredo. Literatura e resistência, op. cit., p. 57. 
E o incêndio levantou estrepitosamente as suas línguas de fogo, e as casas estalavam com fragor - e os homens e as mulheres delirantes pelo meio das ruas - envoltos em fumo e alumiados pelo reverbero das chamas.

E o sangue corria pelas ruas - e as espadas estavam tintas em sangue - e por toda a parte havia sangue.

Era uma cena de pavor, - de luto e desespero - de pranto e de glorias.

E por toda a extensão do vasto Império houve um estremecimento, pressago de que cedo ou tarde seriam também eles vítimas da mesma crueldade. ${ }^{32}$

Tendo acontecido uma vez, o evento acontece e virá a acontecer como lei inexorável. A provável herança maldita da cultura portuguesa faz com que o aqui e o agora do presente da enunciação seja algo que sempre existiu e existirá.

\section{O Conflito entre o Patriarca e o Letrado}

As personagens principais de Meditação são indivíduos que, como prefere o poeta, "gozam da luz da aurora". Ao longo da obra de Gonçalves Dias, as figuras da juventude e da velhice encarnam a antítese entre início e fim da vida, luz e treva, crença e dúvida, partilhando da filosofia humanista e da ética cristã. Em conjunto, polarizam sintetizando o conhecimento:

Infante e velho! - princípio e fim da vida! -
Um entra neste mundo, outro sai dele,
Gozando ambos da aurora; - um sobre a terra,
E o outro lá nos céus. - O Deus, que é grande,
Do pobre velho compensando as dores,
O chama para si; o Deus clemente
Sobre a inocência de contínuo vela.
Amei do velho o majestoso aspecto
Amei o infante que não tem segredos,
Nem cobre o coração co'os olhos d'alma.
A ríspida franqueza amei do velho,
E as rígidas verdades mal sabidas,
Só por lábios seus pronunciadas.

Em "Prodígio", outro poema do autor da série "Visões", Deus lança sua ira sobre os habitantes de uma vasta capital, condenando-os a sofrer uma morte estética pela qual eles se metamorfoseiam em pedra vivente, forçados a se tornar eternos espectadores de seus próprios atos. Pela condenação, os autômatos repetem ininterruptamente seus hábitos em vida, vazios de significado espiritual, como a contabilidade de montes de ouro e a venda de seda damasquina. Só um velho escapa da danação, desde que cultivara o hábito de ler o Alcorão: “- Num largo,/ Fofo e vasto divã, um velho/ Os

32 DIAS, Gonçalves. Meditação, in: Poesia completa e prosa recolhida, op. cit., p. 773. 33 Idem. "Quadras da minha vida", in: Poesia completa e prosa recolhida, op. cit., p. 186. 
versos lia do Alcorão; - só ele/ Dentre tanto punir ficara ileso". ${ }^{34}$ Em Meditação, o traço mais saliente do ancião vidente refere-se a sua constituição como um sábio que, meditando sobre a experiência, detém um saber do mundo prático e pode antever o futuro.

Ao longo da obra de Gonçalves Dias, a construção do velho sábio guarda ainda resquícios do épico. Recorrentes também em Alexandre Herculano, o modo de figuração do idoso evidencia a intenção do poeta brasileiro de valorizar a transmissão da tradição ao longo das gerações. O diálogo entre as gerações favorece a perpetuação da “imagem do passado heroico [...] no qual estão os ancestrais, os pais, os fundadores, os primeiros, os melhores". ${ }^{35}$ Nessa construção e transmissão de valores como tradição, o velho torna-se um cantor-narrador que recebeu "do imaginário nacional os dados mítico-lendários e históricos que povoam a sua narrativa, em relação aos quais ele se coloca como descendente, como ocorre em 'O Poema Americano' ou em 'Os Timbiras"." ${ }^{36}$

Ao constituir seu sujeito lírico e narradores como heróis da comunidade, Gonçalves Dias torna verossímil e reivindica para o poeta a autoridade do relato de feitos heroicos pregressos e da invenção da tradição nacional. No poema "Índio" que forma com "Satélite" outra série, também denominada "Visões", esta póstuma, ${ }^{37}$ a imaginação do sujeito poético põe-se a viajar pelo tempo até se deter em um bosque cujas folhas lhe "rumorejam", "futurando-lhe”, “casos de feio azar". Aí encontra um dos primeiros chefes tupis cuja pureza da fala a destitui de acentos que o convívio com os brancos teria infiltrado posteriormente na língua de seu povo. Esse traço de sua fala evidenciaria a sua ascendência. No diálogo entre eles, o tupi procura compreender o significado da função de cantor com que o sujeito poético se identifica. Na tradução, entende que, não sendo este Tupã, ele seria, como o piaga, aquele que $\mathrm{O}$ recebe em sonhos, numa palavra, um profeta:

\footnotetext{
Ah! feliz cantor! quando ele fala,

A voz dos Manitôs se escuta, e a língua

De nossos pais, que além dos Andes moram.

A Tribo dos tupis - também num tempo

Foi rica de cantores, que ora o povo
}

34 Id. "Prodígio", in: Poesia completa e prosa recolhida, op. cit., p. 145-146.

35 Cf. BEZERRA, Paulo. "As odisseias de Gonçalves Dias”, in: "Caderno de Sábado", Jornal da Tarde, op. cit.

36 Id., ibid.

37 Essa série de poemas, segundo o organizador de uma das edições da obra de Gonçalves Dias, Alexandre de Carvalho Leal, fazia parte da série homônima de Primeiros Cantos e teria sido engavetada pelo autor que a considerava inferior a esta. 
Luta contra Anhangá - prófugo e fraco,

E mais que feitos - ou vitórias cisma

A fuga do vencido sem combate!... ${ }^{38}$

No segundo capítulo de Meditação, o diálogo sobre a estrutura socioeconômica do país é substituído por um inflamado debate acerca da função do letrado na tarefa de construção da nação. O Jovem entende que a descrença diante dessa tarefa deriva da idade senil que despreza novas ideias e esperanças de redenção nacional. Ainda que reconheça que cabe ao idoso esclarecer a sua alma, acusa-o de mentir quando desqualifica a missão do letrado de reformar a sociedade pela ideologia do progresso:

Porque uma infinidade de mancebos se ergueu diante dos teus olhos como um bando de voláteis de sob os pés do viandante que vai distraído, por meio da floresta sem caminho.

E eles se ergueram - bons de vontade, símplices de coração, e ardidos de inteligência - e vão a caminho do progresso a passos de gigante.

Eles marcham rápido como a corrente de catadupa, como a bala inverossímil, e ai do que ousar interpor-se-lhes.

Eles galgam montes e precipícios, como os pombos do Levante, como os corcéis da Ucrânia, como a zebra indomável. ${ }^{39}$

A tréplica do idoso prevê, no entanto, diferentes critérios para o desenvolvimento da nação. Rejeitando a função social que o Jovem destina a si e à sua corporação, seu interlocutor acusa-o de transformar o esclarecimento em instrumento de dominação. Para ele, a sociedade que garante liberdade, educação moral e religiosa e igualdade na distribuição de seus bens prescinde de qualquer intermediação ou voz que represente seus cidadãos:

Mas vós dissestes no vosso orgulho - "O povo manda - o povo é soberano: e eu governo o povo.

Porque eu lhe infundo respeito, e ele aninha minhas palavras no fundo do seu coração, como em vaso cerrado um licor precioso.

Porque eu o intimido com a minha presença, e ele se curva diante de mim como um tigre diante do homem que o soube domar.

Porque eu não censuro os seus vícios, nem repreendo as suas maldades; mas protejo vícios e maldades, que me não prejudicam, e domino por via da lisonja".

E o povo disse: - "Se eles nos lisonjeiam, é porque somos os mais fortes, e se sofremos, por que também não faremos sofrer?!

Não nos disseram eles: 'O homem é livre!' E o que é ser o homem livre se não pode fazer aquilo que lhe aprouver, semelhante à cria do onagro!

Não nos disseram eles: 'Todos somos iguais, somos todos irmãos'. E o que é sermos iguais, se não formos todos aferidos pela mesma medida? O que é sermos todos irmãos, se não é que devemos ter todos uma igual porção de bens, como se partilha a herança de um pai pelos filhos que lhe sobrevivem?"

38 DIAS, Gonçalves. "O índio", in: Poesia completa e prosa recolhida, op. cit., p. 597.

39 Id. Meditação, in: Poesia completa e prosa escolhida, op. cit., p. 750. 
Eles o dirão! E no aferimento lançarão na balança todos os seus vícios e turpitudes para constratar a ciência e virtudes daqueles, de quem se dizem iguais.

E para que o fiel da balança os não atraiçoe no dia em que reinar a soberania do povo, eles interporão a lâmina da sua espada, e ai do que ousar ir contra a força, por que ela é soberana. ${ }^{40}$

Com essa análise, o Velho ganha novos traços, encarnando ainda uma consciência que se aproxima do socialismo de Laemnnais. Nessa posição, coloca o Jovem diante da contradição de reivindicar a soberania popular sem a contrapartida da divisão igualitária de bens materiais. Longe de solucionar o impasse, o Jovem propõe, na antevéspera da Conciliação estabelecida no Segundo Reinado, uma fusão da experiência prática do idoso com o entusiasmo imaginativo do letrado:

E quem sabe? Acaso não resulta o clarão do relâmpago do choque de duas nuvens carregadas de eletricidade opostas?

Pois talvez que a verdade resulte da imaginação e da experiência a imaginação, que é fogo e crê, e a experiência que é gelo e duvida. ${ }^{41}$

Ao deter a capacidade de esclarecer a alma do Jovem quanto à viabilidade do projeto de construção da nação, o Velho encarna a mística sabedoria prática da experiência, representante da memória coletiva supostamente recolhida na tradição. Dotado de profundo conhecimento dos problemas que assolam o país, tendo em vista ainda os longos anos de meditação sobre a cultura local, ele se vê apto a prever o futuro com a mesma presciência com que "Deus lavra seus decretos". Tendo em vista a capacidade do Velho de questionar e ponderar os ideais nacionalistas, bem como de prever o futuro, ele se torna um símile da figura do piaga. Elemento de culto e respeito entre os membros de sua tribo, esse profeta, tal como descrito em Gonçalves Dias, leva uma vida contemplativa, reclusa em cavernas. Após prévia iniciação, pode receber mensagens reveladas por Tupã em sonho, o que lhe faculta antever o futuro. Prevendo guerras e toda sorte de augúrio, como a seca e a invasão de suas terras pelo inimigo, esse poeta-profeta viveria em estreita comunhão com a natureza. ${ }^{42}$

O Jovem, por sua vez, personifica as Luzes, detentor de um conhecimento fundamentado na leitura e no estudo, contraposto ao pragmatismo cético do Velho.

Nesse conflito entre as forças da magia e do esclarecimento, Gonçalves Dias cria um singular mito fáustico, ${ }^{43}$ distribuído em duas consciências opostas, mas não

40 Id., ibid., p. 754.

41 Id., ibid., p. 755.

42 Sobre a descrição da função do piaga entre os tupis, cf. a nota de Gonçalves Dias a "O Canto do Piaga", in: Primeiros cantos. Obras poéticas de, op. cit., p. 31.

43 WATT, Ian. Mitos do individualismo moderno: Fausto, D. Quixote, Don Juan, Robinson Crusoé, op. cit., p. 27. 
antagônicas. Em Meditação, o conhecimento do mundo sobrenatural é prerrogativa da idade provecta. Sem polarizar por exclusão as duas fontes da sabedoria, o mito fáustico como um indagador insaciável apazigua-se positivamente em Gonçalves Dias, pressuposto como resultado da fusão ideal entre experiência e racionalismo. ${ }^{44}$

Ao pleitear a fusão das duas tradições distintas do conhecimento, a mágica e a iluminista, Meditação aponta para o início do processo de progressiva transferência do prestígio "dos senhores da casa-grande pelos negociantes do sobrado urbano", quando se inicia a ocupação dos quadros funcionais do Estado-nação pelos letrados locais. Nesse momento, a abertura dos portos ao estrangeiro começa a contribuir para intensificar o comércio, em prejuízo da agricultura e da indústria pastoril, marcando "o germe de uma vida, diferente da rural". Logo em seguida, o crescimento da importância do comércio marítimo e a renovação dos meios de transportes ferroviários desencadearão profundas transformações na paisagem acanhada da Corte, dando origem à urbanização. ${ }^{45}$

Durante o reinado de D. Pedro II, diz Gilberto Freire, o progressivo declínio do prestígio do patriarca ocorre paralelamente à ascensão social do bacharel, seja ele branco ou mulato, filho legítimo ou ilegítimo de grandes senhores de engenho, ou mesmo de senhoras quitandeiras que se sacrificavam para enviar o filho para estudar na Europa. Após se graduar lá fora - a maior parte, segundo Gilberto Freyre, em direito ou medicina, e em menor escala, em filosofia ou matemática -, o letrado retorna ao país com novos estilos de vida e hábitos do vestuário aburguesados que contrastam com o estilo de vida rural dos velhos administradores: "[Os bacharéis] trazendo com o verdor brilhante dos vinte anos, as últimas ideias inglesas e as últimas modas francesas, vieram acentuar, nos pais e avós senhores de engenho, não só o desprestígio da idade patriarcal, por si uma mística, como a sua inferioridade de matutões atrasados". ${ }^{46}$

Nesse período, a ascensão social do letrado aos quadros do Estado nacional coincide com o projeto do governo imperial de conter a interferência do patriarca e dos

44 Em Gonçalves Dias, a enfática adesão a princípios iluministas leva um de seus contemporâneos, Macedo Soares, a lançar a suspeita, num artigo de 1859, acerca do vigor da religião no pensamento do poeta: “A religião dos Primeiros Cantos não era, com efeito, uma fé robusta: o poeta duvidou, cobriu-lhe o coração o crepe do ceticismo: sua alma passa por uma transformação notável: pensa, calcula, mede as distâncias, faz os cômputos dos tempos e vê que as distâncias são insuperáveis e difíceis os tempos". SOARES, Macedo. "Tipos literários contemporâneos I. Gonçalves Dias", in: CASTELLO, Aderaldo (org.). Textos que interessam à história do romantismo, op. cit., p. 104.

45 Cf. AZEVEDO, Fernando. A cultura brasileira, op. cit., p. 138-139.

46 FREYRE, Gilberto. Sobrados e mucambos: decadência do patriarcado rural e desenvolvimento do urbano, op. cit., p. 575. 
líderes políticos das províncias na condução da política central. ${ }^{47}$ Nesse "reinado dos bacharéis", o governo de D. Pedro II fez conviver a mística da sabedoria extraída dos estudos com a prática dos velhos administradores destronados:

Destes [os velhos administradores] se pode dizer, na verdade que estavam para os filhos e netos, formados em Direito e em Filosofia, ou em Matemática e Medicina, na Europa, ou sob a influência francesa ou inglesa, como muito curandeiro da terra para os rapazes formados em medicina em Montpellier e em Paris: superiores aos doutos - os curandeiros - pelo seu traquejo e pela sua prática; pela sua sabedoria de grandes intuitivos que lidavam face a face com os males e as doenças do meio tão diverso do europeu, que conheciam pelo nome e às vezes pela experiência do próprio corpo, as resinas, as ervas e os venenos indígenas ou trazidos da África pelos negros. ${ }^{48}$

O hábito de refletir sobre a prática política no Brasil, a convicção, assentada na experiência, de que a adoção do nacionalismo - num país que se ressentia do trabalho formal, de educação pública e da desigual distribuição de seus bens - era mera ideologia de dominação torna o Velho cético com a possibilidade de solucionar, em médio prazo, as contradições sociais do país. O Jovem, por sua vez, possui uma clareza parcial da vida, extraída exclusivamente da teoria. Seu idealismo prescinde da experiência com a cultura local, o que torna estéreis suas formulações e soluções. Sua falta de diálogo com a cultura do país dificulta, para o Velho, a superação dos descaminhos que a escravidão encarrilhava:

Meu filho, a verdadeira ciência não se colhe dos livros: ela vem com a meditação.

A meditação - essa filha do céu, que desce sobre o coração do solitário, tão silenciosa e docemente como o orvalho noturno sobre o cálix de uma flor.

Rainha grave e madura, que não traja o ouropel da imaginação, que não se adorna com pedrarias, porque ela é sublime na sua simplicidade, majestosa no recolhimento do seu porte.

Esse livro d'alma, que vós outros mancebos não consultais, porque é austero e cheio de rigidez nos seus ditames, e porque não vos fala a linguagem acalorada e veemente das paixões. ${ }^{49}$

Para o Jovem, no entanto, o mérito de seus ideais reside precisamente em sua capacidade imaginativa, o que o leva, a despeito dos exemplos históricos, a insistir na viabilidade de suas utopias. A subjetividade fáustica dessa obra não explora o isolamento social da moderna consciência individualista cavalgando imaginariamente por terrenos desertos ou mesmo dilacerada diante da adversidade. Na hipótese de que

47 Sobre o prestígio dos bacharéis ao longo do século XIX, cf. tb. CARVALHO, José Murilo de. $A$ construção da ordem. Teatro das sombras, op. cit., p. 63-92.

48 FREYRE, Gilberto. Sobrados e mucambos: decadência do patriarcado rural e desenvolvimento do urbano, op. cit. p. 581.

49 DIAS, Gonçalves de. Meditação, in: Poesia completa e prosa escolhida, op. cit., p. 750. 
entre a severidade da experiência e o devaneio da juventude nasce a verdade, a antitética, mas não paradoxal, posição ideológica de ambos poderia sintetizar as soluções para o impasse em que o país se encontrava: o velho teria a oferecer o conhecimento dos erros do passado, e o Jovem, por sua vez, tornaria-se apto a intermediar os conflitos entre o povo e a elite política. Essa interação permite, num primeiro momento de Meditação, avaliar os problemas econômicos, sociais e culturais que emperravam a adoção desse ideal, traindo, nesse caso, uma preocupação quanto aos riscos de se transplantar aleatoriamente o nacionalismo, sem a necessária observação das condições locais. Mas também não deixa de trair um anseio para que se defina um lugar funcional para o letrado e para a literatura no interior das instituições nacionais, antevisto como uma espécie de conselheiro político.

Em 1845, mesmo ano em que o poeta inicia a composição de Meditação, a Inglaterra, como se sabe, decreta o Bill Aberdeen e pressiona o Brasil a extinguir o tráfico de escravos, outorgando-se plenos poderes para aprisionar e julgar navios negreiros. Nesse contexto, a condução progressiva da eliminação da escravidão vigorava na pauta do dia, sendo reconstruída, em Meditação tanto catolicamente, como um sacrifício do povo brasileiro, tanto romanticamente na ideia de que sua superação conformaria uma etapa intermediária rumo à conquista do capitalismo desenvolvido. Ora representada na imagem de Laocoonte, ora nas enormes proporções do Colosso, a revolta dos escravos é ameaça permanente em Meditação:

E o colosso tinha as feições horrivelmente contraídas pela raiva, e com os braços erguidos tentava descarregar ás mãos ambas um golpe que seria de extermínio.

E a vítima era um povo inteiro; eram os filhos de uma numerosa família, levados ao sacrifício por seus pais - como Abraão levou a Isaac, seu filho.

E como Isaac também eles acordaram com as espadas sobre as suas cabeça, e o seu despertar foi terrível, porque somente Deus os poderia salvar. ${ }^{50}$

Nessa forma singular de interpretar o fim da escravidão, o Jovem virtuoso do último capítulo sempre salienta seu lugar intermediário entre a população de homens pobres livres e a elite política. Para tanto, Meditação também contrapõe duas espécies distintas de ilustrados. No momento da outorga do acordo político nada democrático, um filósofo trai o respeito "à diversidade das opiniões", alia-se aos proprietários para "racionar sobre as cousas como elas são e não como devem ser". Em contraposição, durante o conselho entre os quatro velhos políticos, o jovem letrado autodeclarado 
virtuoso toma para si a tarefa de propagar ideias progressistas, despertar a consciência patriótica no Brasil e persuadir o pobre a se entregar voluntariamente ao trabalho de construção da infraestrutura da nação. Ao se delegar essa função, mas em diálogo direto com velhos políticos, o jovem literato dirige seu discurso à elite política, alertando-a da utilidade do pensamento concebido com a função de questionar a improvável apatia secular da população.

Meditação funciona, assim, como uma revisão da função pragmática da literatura. Em "Discurso da história da literatura brasileira", o narrador de Gonçalves de Magalhães reconstrói a história do Brasil exagerando o efeito nocivo do sistema político português sobre o baixo desenvolvimento da dita "inteligência nacional". Com isso, desvia a atenção da escravidão para insistir nos dons artísticos naturais do indígena como fonte de inspiração da musa nacional. Ao traçar as etapas da história do Brasil, Magalhães define de modo vago e impreciso do "Espírito" das épocas, entendendo-o como uma razão nacionalista e católica que teria evoluído progressivamente até atingir o ápice com sua época. Ao se colocar a serviço da política dominante, seu elogio e representação da presença ativa do letrado ao longo dos períodos da história colonial projeta o anseio por redefinir a função social do autor no Brasil independente, outorgando-se a tarefa de orientar e remodelar as jovens consciências letradas.

Em Gonçalves Dias, por sua vez, a valorização do modo de produção formal evidencia o leitor implícito a que sua obra se destina. Propõe despertar, na consciência política, a utilidade de uma campanha literária que alerte o trabalhador a optar ou pela vida ociosa e, assim, à precariedade, ou pela racionalidade do trabalho formal. No interior de Meditação, a formulação dessa decisão não se faz acompanhar da devida valorização da ideologia burguesa ditando que "a paga anima o trabalho". Essa formulação antes se apoia no culto cristão do sacrifício, evidenciado na pressuposição de que sejam nobres e sagrados o esforço físico e o sofrimento derivado da mão de obra empregada na construção da nação. O narrador jovem acredita possível algum tipo de ação que altere a suposta ociosidade dos pobres livres por uma produtividade a que eles deveriam se predispor em nome do progresso, da nação e da civilização para poucos. $\mathrm{Na}$ viagem de volta ao Brasil, enquanto aqui se instala, Gonçalves Dias critica a preservação do modo de produção forçado e, concomitantemente, formula princípios que afirmam a utilidade da literatura para alterar esse quadro. Pondo-se em diálogo direto com a elite dominante, busca chamar-lhe a atenção e valorizar a contribuição dos ideólogos e literatos para a administração do Estado. Para ele, a obra de construção da 
nação exigiria uma mudança de atitude, seja na forma de governar, seja no modo de vida dos homens pobres e livres, improvavelmente propensos à indolência. A figura do intelectual por ele concebida não se coloca apenas como um defensor incondicional dos interesses da elite política, mas como uma espécie de conselheiro de assuntos políticos e culturais. Assim fazendo, Meditação remodela e perpetua a antiga função utilitária da literatura. Sua compreensão negativa da história do Brasil evidencia a motivação voltada para reformular a divisão do trabalho de tal modo que o letrado possa ser aí inserido. Interpretando a reforma política nacional como necessidade de todos, universaliza um interesse particular. Gonçalves Dias pressupõe, ao fim e ao cabo, um implícito leitor que abarca quer o círculo restrito de escritores e intelectuais, quer a camada dominante que precisaria ser convencida quanto à utilidade da literatura de cunho nacional.

\section{A Forma do Fragmento}

As principais características estilísticas do drama Meditação residem em seu inacabamento formal e na fusão dos gêneros. $\mathrm{O}$ texto foi originalmente publicado pelo próprio autor em 1850, nos seguintes números da revista Guanabara, com o subtítulo de "Fragmento":

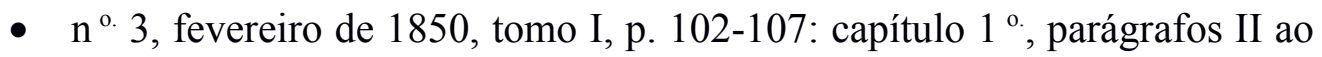
VII;

- $\mathrm{n}^{\mathrm{o} .} 4$, março de 1850 , tomo I, p. 125-134: capítulo $2^{\circ}$, parágrafoS II ao XIII;

- $\quad \mathrm{n}^{\text {o. }} 5$ de 1850 , tomo I, p. 171-177: capítulo $3^{\circ}$, parágrafos I ao $\mathrm{V}^{51}$

Nessa publicação original, os dois primeiros capítulos não continham o subcapítulo introdutório, e ao último faltavam as subseções seis a treze. Essa disposição do texto na Guanabara corresponde quase integralmente à edição que hoje se conhece, postumamente publicada por Antonio Henriques Leal (1868-1869). Inexistentes na princeps, os sete subcapítulos finais do último capítulo, na edição de Leal, referem-se ao segundo diálogo entre o jovem e os políticos envolvidos nas lutas regenciais representadas pelo fogo infernal como um eterno presente. É provável que estas passagens tenham sido autocensuradas, ou escritas posteriormente à publicação na revista. Mas a primeira subseção dos capítulos um e dois jamais foram conhecidas desde

$51 \mathrm{Cf}$. LOPES, Hélio. A divisão das águas: contribuição ao estudo das revistas românticas Minerva Brasiliense (1849-1856) e Guanabara (1843-1845), op. cit., p. 311-313. 
o início, indicando que ou foram definitivamente cortadas pelo próprio autor, ou jamais existiram. $^{52}$

A ausência dos parágrafos iniciais dos primeiros capítulos não inviabiliza, no entanto, a hipótese de que Gonçalves Dias possa ter pretendido modelar, conforme o subtítulo, seu texto pela forma do fragmento romântico. Considerando que, após a sua morte, não havia mais risco de o poeta ser prejudicado pela publicação de um texto polêmico, de acordo com a suspeita de Lúcia Miguel-Pereira; e que, assim, Henriques Leal poderia ter publicizado os subcapítulos suprimidos caso eles de fato existissem; e ainda o prestígio do fragmento no século XIX e que a decisão do autor de publicar uma obra inacabada pode ter sido favorecida por esse prestígio; levando em conta ainda que o inacabamento de Meditação não reside apenas em sua forma externa, mas também em seu historicismo que concebe o fluxo do tempo como uma sempre-eterna reprodução do Mesmo; levando tudo isso em consideração pode-se supor que, mesmo que a fragmentação do texto decorra das circunstâncias, estas não eliminam a presença de certos aspectos formais do fragmento romântico. Mesmo que o traço mais evidente da indeterminação formal de Meditação sejam aqueles parágrafos nunca conhecidos, isso não apaga outros traços do inacabamento.

A prosa bíblica de Gonçalves Dias apresenta um capítulo final, mas não uma solução dos impasses sociais e econômicos armados ao longo da narrativa, o que o leva a abrir e fechar um círculo. Uma vez que a supressão das subseções introdutórias dos capítulos I e II não impede a compreensão do conjunto, ele contém começo, mas não introdução, fechamento, mas não conclusão. O principal procedimento responsável pela fragmentação da obra consiste na expressão e representação da razão crítica que favorece a mistura das áreas do conhecimento e dos gêneros. Com isso, a despeito das circunstâncias, o suposto corte tendeu a acentuar a natureza da aparente forma sem forma.

Tal como previsto programaticamente pela teoria crítica do romantismo alemão, o fragmento cultiva a contradição, apresentando uma estrutura inacabada, mas não incompleta. A figuração do pensamento crítico-especulativo no interior da obra de arte

52 Segundo Lúcia Miguel-Pereira, Gonçalves Dias, em 1846, remeteu o segundo capítulo de Meditação para São Luís, para que o amigo Teófilo o publicasse no jornal literário $O$ arquivo. Na carta em que despacha o capítulo, o poeta assim se manifesta sobre o texto: "cortem sem dó, - o que julgarem mau - ou perigoso de imprimir” (DIAS, Gonçalves. Carta a Teófilo, 2-12-1846, apud MIGUEL-PEREIRA, Lúcia. A vida de Gonçalves Dias contendo o diário inédito da viagem do autor ao Rio Negro, op. cit., p. 132). Desconhecem-se, no entanto, as razões para que o texto não tivesse sido publicado: "Talvez tivessem julgado desasado o momento para criticar uma instituição mantida pelo governo, justamente quando o poeta dependia das boas graças oficiais para obter colocação" (Id., ibid.). 
prevê a justaposição e o jogo entre ideias antitéticas, projetando a busca de seu sentido para além da leitura. Definida por Schlegel como uma instância privilegiada do conhecimento, a obra de arte é produzida pela incorporação em seu interior da ação reflexiva do pensamento que pensa a si mesmo, infinita e progressivamente, de grau em grau como "um pensar do pensar", um "pensar do pensar do pensar" e assim por diante, num esforço utópico de alcançar a imediatez da inapreensível intuição intelectual, vale dizer, o Eu absoluto. Contrapondo a teoria do conhecimento de Schlegel e Novalis à de Fichte, Walter Benjamim afirma que, nos primeiros, a infinitude da reflexão crítica não desemboca "num percurso infinito no vazio", podendo ser compreendida como uma dialética negativa em que cada pensamento anteriormente formulado, ao ser tomado como objeto de uma nova reflexão contraposta à primeira, conecta-se ao pensamento anterior para, em seguida, engendrar um novo infinitamente, numa sequência em que ao simples pensar, segue o pensar do pensar, etc., dando origem aos graus infinitos da reflexão. Trata-se, assim, de uma infinitude de conexão cuja ambiguidade espera abalar o causalismo lógico do racionalismo:

A rígida forma originária da reflexão do segundo grau [o pensar do pensar] é no terceiro abalada e acometida pela ambiguidade cada vez mais múltipla. Nesta constelação material assenta-se o peculiar da infinitude da reflexão a que os românticos recorrem: a dissolução da forma própria da reflexão diante do absoluto. A reflexão estende-se sem limites e o pensamento formado na reflexão torna-se pensamento sem forma, o qual se dirige para o absoluto. ${ }^{53}$

Ao fundamentar a teoria do conhecimento na infinitude da reflexão, os românticos praticam a implosão dos limites dos gêneros tradicionais. Resultado da exigência de se pensar criticamente questões filosóficas e estéticas do ponto de vista da filosofia da história e, no mesmo intuito, transpor os domínios das diferentes áreas do conhecimento, a reformulação dos gêneros como estética, não como teoria pragmática, leva Schlegel a propor a dissolução dos limites entre o lírico, o épico e o dramático. ${ }^{54}$ Ao pensar o discurso poético como autorreflexão infinita, movimentando os assuntos pelos diversos registros estilísticos, o efeito alcançado, diz João Adolfo Hansen, “impede que a consciência do leitor se fixe em qualquer objeto determinado". O movimento por diversos assuntos e gêneros no interior de uma mesma narrativa cria o efeito de indeterminação do sentido, pois “o mundo objetivo se liquefaz, náusea e tédio,

53 BENJAMIM, Walter. O conceito de crítica de arte no romantismo alemão, op. cit., p. 40.

54 Sobre a formulação de uma poética dos gêneros a partir da oposição, em Schlegel, entre a antiga teoria pragmática e o método especulativo filosófico, cf. SZONDI, Peter. Poésie e poétique de l'idéalism allemand, op. cit., p. 117-143. 
que escorrem interpretados com a exasperação da falta de sentido do ato mesmo de expressá-la. All was tainted with myself, como diz D. H. Lawrence. Não se fixando em nada, o gênio assume o diabolismo da indeterminação", ${ }^{55}$

Nessa exigência de implosão da estrutura fechada e da simetria clássica, o fragmento torna-se, em Schlegel, uma das formas mais reputadas, pois propicia, pela exposição de pontos de vista antagônicos, a destruição da reflexão unilateral e a instauração da crítica como possibilidade de elevar o pensamento acima da doxa e de dogmas. No fragmento, a oposição dialógica entre visões distintas procura condicionar mutuamente "os extremos entre os quais oscila a reflexão", ${ }^{56}$

Em Meditação, Gonçalves Dias não explora, no entanto, múltiplas conexões da reflexão na autoconsciência refletindo a si mesma. Mesmo quando o Velho aponta a contradição de um pensamento que prevê soberania popular, sem pressupor a defesa dos direitos individuais, o Jovem faz vista grossa ao problema. O confronto entre a consciência juvenil e a de seu antípoda idoso desemboca, no máximo, numa reflexão de segundo grau, uma reflexão acerca do pensamento pensado sobre a nação. Em que pesem as divergências, nenhuma dessas consciências nega o liberalismo pressuposto nas propostas de desenvolvimento do Brasil. Se divergem quanto aos meios, unificam-se, no entanto, na crença do progresso sob certas condições. A adesão à ideologia nacional afasta a possibilidade de fragmentar a consciência crítica e a forma artística na plenitude do ceticismo e do niilismo, da ironia e da autoparódia.

Meditação pode ser, assim, compreendida como um fragmento peculiar cujo incipiente inacabamento prevê a inserção da reflexão crítica, mas não da autocrítica. Trata-se de uma reflexão poética que não implica o embate com seus próprios princípios ético-políticos e com seus procedimentos artísticos, previamente e positivamente avaliados. A atenuação da forma do fragmento liga-se a um pensamento reformista e cristão que, ao polemizar com a autoridade do antigo, minimiza a possibilidade de asseverar um pensamento monológico. A fragmentação embrionária da forma e do conteúdo alcança expor dois pontos de vista críticos sobre a mesma questão, mas sem destroná-la completamente. Apesar de não indeterminar o conteúdo ao limite da ironia que destrói ininterruptamente visões antagônicas de mundo, justapondo-as uma a outra, os principais aspectos de Meditação que permitem defini-la como um incipiente fragmento encontra-se na exposição e representação da crítica social, política e 55 Cf. HANSEN, João Adolfo. "Forma romântica e psicologismo crítico", no livro de minha autoria $O$ Belo e o disforme. São Paulo: Edusp/Fapesp, 1998, p. 13-14.

56 Cf. SUZUKI, Márcio. “A gênese dos fragmentos”, in: $O$ dialeto dos fragmentos, op. cit., p. 15. 
intelectual de seu contexto de produção, e no aproveitamento mesclado dos gêneros tradicionais.

Neste sentido, a estilização do estado de alma arrebatado no interior da narrativa freia a ironia autocorrisiva, mas proporciona a expressão do lírico na representação epicizante, forjando a mistura de poesia e prosa. Meditação conforma-se como um misto de filosofia da história, crônica histórica, mito e maravilhoso, programa literário, manifesto abolicionista e ensaio poético, distendendo-se pela forma dramática e com tensão dramática.

Por outro lado, a estilização de personagens prosaicas - o patriarca-político, o universo dos trabalhadores e o letrado - ao lado de outras míticas - o sábio vidente e a comunidade indígena heroica - torna problemático que o baixo, tradicionalmente pensado, ganhe seriedade trágica e forje, com isso, a mistura estilística. A intensificação seguida da limitação da energia vital do Jovem pela perda de sua consciência evidencia a tentativa de hierarquizar o drama individual do poeta inserido em condições históricas adversas.

Hierarquizando esse drama em detrimento da vida social, Meditação deixa de problematizar a vida dos trabalhadores como assunto sério. Os "operários", como são nomeados no texto, não ganham voz, o que mimetiza e confirma a sua exclusão da estrutura social brasileira. A representação desse segmento como uma massa de homens indolentes e ignorantes, assim como a descrição da elite política por meio de chavões que a compõem como uma camada simplesmente viciosa, enfim, ao traçar caricaturas morais e desqualificar, equiparando, os dois estratos sociais antagônicos, o autor toca na desigualdade social do Brasil escravocrata, mas se desobriga de aprofundar a discussão. Ressalte-se ainda que, em Meditação, o pouco aprofundamento das contradições sociais não se deve necessariamente a uma suposta ausência, no contexto intelectual do autor, de uma consciência política atenta a esses problemas. O próprio Velho socialista denuncia que a falta de distribuição dos bens materiais, de igualdade e liberdade encontram-se entre os fundamentos do atraso do país. A tipificação negativa dos dois segmentos sociais antagônicos deriva antes do privilégio concedido aos ideais do jovem poeta e ao liberalismo cristão do autor, figurado como profeta dotado da nobre missão de pensar um projeto para o país.

Em Meditação, a representação dos conflitos sociais não explora os efeitos da escravidão e a negação dos direitos humanos na consciência do indivíduo que a sofre. Ao subordinar a resolução dos problemas sociais à angústia e ao anseio do Jovem por 
definir um lugar social para sua corporação na hierarquia estamental, o texto desloca esses problemas da esfera coletiva para a individual. A reflexão aí não questiona os desatinos do nacionalismo restrito a poucos, mas antes acentua o pathos, a dor provocada pelo pragmatismo dos políticos antigos e pelos descaminhos forjados pela escravidão. Com isso, afasta-se a possibilidade de configurar a história do Brasil pela estrutura discursiva do sublime, conforme Schiller.

Em sua teoria acerca desse estilo, o poeta alemão prevê, como objeto estético, cenas da história da humanidade dotadas de um poder dinâmico que ameaçam a liberdade. A representação dessa história como uma força inapreensível que abala o ânimo de seu espectador pressupõe uma forma informe e uma oportunidade para que o herói ofereça resistência moral ao sensível e ao finito e, com isso, afirme sua autonomia.

Inversamente, Gonçalves Dias privilegia a impotência do herói de Meditação para reagir a fenômenos sociais que negam a ação livre das paixões e força física. ${ }^{57}$ Nesse sentido, os três quadros da história brasileira que ameaçam a energia vital e levam o Jovem ao desmaio referem-se à imagem que representa a indolência do homem livre não-proprietário; à réplica do Velho de que a proposta de adoção da soberania popular não passava de mentira e de uma forma de dominação pelo saber; e, finalmente, após a cena em que velhos políticos insuflam a discórdia e alastram o fogo pelo país afora. Nessas três sequências, a supressão da consciência do Jovem tangencia a resignação e evidencia, em Schiller, o embotamento da razão provocado pelo violento choque entre esta e a imaginação.

Se, ao estilizar o drama individual de modo patético, a intenção tenha sido elevar os ideais do jovem liberal acima dos demais agentes da história do Brasil, desqualificados e unificados na atenção ao necessário-sensível, a adesão do jovem letrado ao liberalismo elimina a possibilidade, inscrita nos moldes do sublime romântico, de oferecer resistência às adversidades sociais. Vale dizer que, ao desmaiar, o eu-juvenil demonstra a impotência da razão para apreender, ajuizar e resistir ao turbilhão da história, o que, ao modo schilleriano, poderia fornecer a via de acesso da arte ao sublime demoníaco negativo. Os desmaios implicam o fracasso das forças espirituais do Jovem diante do poder potentemente dinâmico e destrutivo da realidade adversa.

57 Lembro que Gonçalves Dias traduziu a Noiva de Messina, de Schiller, tendo se apropriado da teoria do sublime schilleriana e dos preceitos do Pseudo-Longino para estilizar, em outros poemas de sua autoria, a história do Brasil, o indianismo e o sentimento nacional como matéria nobre. 
A representação trágica dos dilemas do herói de Meditação diante da história brasileira incorpora antes os conselhos de Pseudo-Longino para forjar a nobreza do discurso. O sentimental atordoamento do Jovem diante das iniquidades do país e a aparente forma sem forma do texto indicam, entre outros elementos, a incorporação do preceito do Anônimo de que é próprio do sublime a clareza da linguagem, mas sutilmente desordenada para que possa, assim, encobrir o artifício artístico e dar a impressão de que a irregularidade discursiva expressa o furor de uma espontânea e arrebatada alma grandiosa.

No texto de Gonçalves Dias, no entanto, a redução dos atores sociais a tipos morais e dos problemas sociopolíticos aos interesses da subjetividade elimina a possibilidade de elevar a representação literária ao limite da grandeza infinita da ideia. Preso a interesses particulares, o assunto, conforme o Anônimo, perde grandeza moral, já que, para ele, o sublime ecoa a humanidade de todos os tempos.

A desqualificação satírica das camadas sociais opostas e desiguais em força unifica-as num mesmo plano. Se os patriarcas políticos são pintados como agentes da desordem social, as personagens previstas como povo não se constituem como sujeitos políticos, apresentando-se como um poder revolucionário meramente latente $\mathrm{e}$ supostamente irracional. Em conjunto, a desfaçatez e o antinacionalismo dos antigos políticos, a figuração da categoria povo como massa apática de mão de obra e também a impotência do Jovem narrador se reduzem a um plano nem tão satírico, nem tão grave.

Ao abordar a abolição da escravidão de um ponto de vista pragmático-liberal e desqualificar a prática política dos dirigentes do país apenas pelo aspecto moral - como se a atrocidade do regime monárquico escravocrata pudesse ser amenizada caso a elite dominante adotasse o dó de peito e estabelecesse uma relação mais humana com os escravos e os excluídos -; ao retratar, por fim, os interesses do jovem letrado de forma sentimental e comovente, o esforço mal sucedido de elevar as aspirações do representante do estrato social médio trai um ponto de vista pequeno-burguês que anseia para si por um lugar social intermediário. A compreensão dos conflitos sociais pela via patética e moral separa dois universos sociais antagônicos de um terceiro, exigindo uma posição de destaque aos bacharéis, candidatos possíveis a mediar a relação entre os demais segmentos.

\section{Referências Bibliográficas}


AUERBACH, Figura. Trad. Duda Machado. São Paulo: Ática, 1997.

AZEVEDO, Fernando. A Cultura brasileira. Rio de Janeiro: UFRJ; Brasília: UnB, 1996.

BEZERRA, Paulo. "As odisseias de Gonçalves Dias", in: "Caderno de Sábado", Jornal da Tarde, 25/4/1998, p. 6.

BOSI, Alfredo. Literatura e resistência. São Paulo: Companhia das Letras, 2002.

CARVALHO, José Murilo de. A construção da ordem. Teatro das sombras. Rio de Janeiro. Civilização Brasileira, 2003.

DIAS, Gonçalves de. Obras poéticas de. Org. Manuel Bandeira. São Paulo: Companhia Editora Nacional, 1944.

Poesia completa e prosa recolhida. Rio de Janeiro: Editora José Aguilar, 1959.

FREYRE, Gilberto. Sobrados e mucambos: decadência do patriarcado rural e desenvolvimento do urbano. Rio de Janeiro: José Olympio Editora, 1968.

GUIMARÃES, Manoel Salgado. "História e natureza em von Martius: esquadrinhando o Brasil para construir uma nação", in: História, Ciências, Saúde-Manguinhos, vol. VII (2), jul-out, 2000. http://www.scielo.3br/scielo.php?script=sci_arttext\&pid=S0104$59702000000300008 \& \operatorname{lng}=$ en\&nrm=iso\&tlng=pt

HANSEN, João Adolfo. "Forma romântica e psicologismo crítico", in: CUNHA, Cilaine Alves. O belo e o disforme. São Paulo: Edusp/Fapesp, 1998, p. 13-14.

. HANSEN, João Adolfo. Alegoria. São Paulo/ Campinas: Hedra/ Ed. da Unicamp, 2006.

HERDER. Também uma filosofia da história da humanidade. Trad. José M. Justo. Lisboa: Antígona: 1995.

JUSTO, José M. Posfácio a HERDER. Também uma filosofia da história da humanidade. Trad. José M. Justo. Lisboa: Antígona: 1995.

LAMENNAIS. Les Paroles d'un Croyant. Paris: L'Abeille d'Or T. Rombaldi Éditeur, 1928

LOPES, Hélio. A divisão das águas: contribuição ao estudo das revistas românticas Minerva Brasiliense (1849-1856) e Guanabara (1843-1845). São Paulo: Conselho Estadual de Artes e Ciências Humanas, 1978.

MARQUES, Wilton José. Gonçalves Dias, o poeta na contramão. Literatura e escravidão no romantismo brasileiro. São Carlos: EdUFSCAR, 2010.

MARTIUS. "Como se deve escrever a história do Brasil". Revista do Instituto Histórico e Geográfico Brasileiro, n. 24, 1844, p. 381 a 403.

MEINECKE. El historicismo y su genesis. Trad. José Mingarro y San Martin e Tomás Muñoz Molina. México: Fondo de Cultura Economica, 1943.

MIGUEL-PEREIRA, Lúcia. A vida de Gonçalves Dias contendo o diário inédito da viagem do autor ao Rio Negro. Rio de Janeiro: Livraria José Olympio, 1943.

SUZUKI, Márcio. "A gênese dos fragmentos", in: $O$ dialeto dos fragmentos. Trad. Márcio Suzuki. São Paulo: Iluminuras, 1998. 
SZONDI, Peter. Poésie e Poétique de l'Idéalism Allemand. Traduction dirigée par Jean Bollack; avec la collaboration de Barbara Cassin, Isabelle Michot, Jacques Michot, Helen Stierlin. Paris: Édition de Minuit, 1975.

Walter BENJAMIM. O conceito de crítica de arte no romantismo alemão. Trad. Márcio Seligmann Silva. São Paulo: Iluminuras/Edusp, 1993.

WATT, Ian. Mitos do individualismo moderno: Fausto, D. Quixote, Don Juan, Robinson Crusoé. Trad. Mário Pontes. Rio de Janeiro: Jorge Zahar, 1997. 